\title{
Academic migration and marijuana use among undergraduate students: evidences from a sample in southern Brazil
}

\author{
Migração acadêmica e uso de maconha entre estudantes de \\ graduação: evidências de uma amostra do sul do Brasil
}

Lauro Miranda Demenech (http://orcid.org/0000-0002-7285-2566) ${ }^{1}$

Samuel C. Dumith (http://orcid.org/0000-0002-5994-735X) ${ }^{1}$

Simone dos Santos Paludo (https://orcid.org/0000-0002-3281-5824) ${ }^{1}$

Lucas Neiva-Silva (http://orcid.org/0000-0002-7526-2238) ${ }^{1}$

${ }^{1}$ Programa de PósGraduação em Saúde Pública, Faculdade de Medicina, Universidade Federal do Rio Grande. Av. Itália km 8, Carreiros. 96201-900 Rio Grande RS Brasil.lauro_demenech@ hotmail.com

\begin{abstract}
The aim of this study was to measure the prevalence of marijuana use in the last month, its associated factors and its relationship with academic migration among undergraduate students of a federal university in southern Brazil. This was a cross-sectional study and data were collected through self-administered questionnaire. A systematic sampling process was conducted. To data analyses, it was used Poisson regression with robust adjust for variance. Overall, 1,423 students participated. The prevalence of marijuana use in the last month was $16.8 \%$ (95\%CI $14.8 \%$ to $18.8 \%)$. Data showed that the greater the distance of the city prior to university entry, the higher the prevalence of marijuana use in the last month. Being male, having less age, being single, not having religious practices, having relatives and friends who have used any illicit drug, and having tobacco use in the last month were also risk factors. We understand that academic migration within the country tends to decrease students contact with family and increase vulnerability to peer influence, which may lead to a higher probability of marijuana use in this sample. The results highlights the importance to develop projects of illicit drug use prevention focused on this risky subgroup.
\end{abstract}

Key words Marijuana, Cannabis, Academic migration, Illicit drugs, Undergraduate students
Resumo O objetivo deste estudo foi medir a prevalência de uso de maconha no último mês, seus fatores associados e sua relação com a migração acadêmica entre estudantes de graduação de uma universidade federal do sul do Brasil. Este estudo teve delineamento transversal e os dados foram coletados através de questionário autoaplicável. $O$ método de amostragem foi aleatório sistematizado. Na análise dos dados utilizou-se a regressão de Poisson com ajuste robusto da variância. Participaram do estudo 1.423 graduandos. A prevalência do uso de maconha no último mês foi de 16,8\% (IC95\% 14,8\%-18,8\%). Os dados mostraram que quanto maior a distância da cidade anterior ao ingresso na universidade, maior a prevalência de uso de maconha no último mês. Ser do sexo masculino, ter menos idade, estar solteiro, não ter prática religiosa, ter familiar e amigo que já usou alguma droga ilícita e ter usado tabaco no último mês também foram fatores de risco. Entendemos que a migração acadêmica no país tende a diminuir o contato dos alunos com a família e aumentar a vulnerabilidade à influência dos pares, o que pode levar a uma maior probabilidade de uso de maconha nesta amostra. Os resultados ressaltam a importância de desenvolver projetos de prevenção focados neste subgrupo de risco.

Palavras-chave Maconha, Cannabis, Migração acadêmica, Uso de drogas ilícitas, Estudantes universitários 


\section{Introduction}

Marijuana is the third most widely used recreational drug in the world, second only to alcohol and tobacco ${ }^{1}$. Following this trend, in Brazil, marijuana is the most commonly used illicit substance $^{2,3}$. Even though there are recent researchs indicating some possible benefits of the use of cannabis in some medical conditions ${ }^{4}$, its use as a recreational drug may have a significant impact on health. It has being associated to an increased risk for motor vehicles accident ${ }^{5}$, to a reduction in the volume of the hippocampus and amygdala in the brain ${ }^{6}$, to the increased likelihood of development of alcohol-related disorders ${ }^{7}$, to the development of psychotic symptoms ${ }^{8,9}$ and to short-term cognitive impairment ${ }^{5}$.

In the Brazilian adult population, it was found that $5.8 \%$ had tried marijuana at least once in their lives, $2.5 \%$ had used it in the last year $^{3}$ and $1.9 \%$ had used it in the last month ${ }^{2}$. The college student population is a subgroup at greatest risk for marijuana use. In 2009, a survey with a representative sample of Brazilian universities pointed out that $26.1 \%$ of the interviewees had tried marijuana (lifetime use), $13.8 \%$ had used it in the last year and $9.1 \%$ had used it in the last month ${ }^{10}$. In the United States, these frequencies are higher, with $47.7 \%$ of lifetime use, $35.5 \%$ of last year use and $20.4 \%$ of last month use ${ }^{11}$.

It is crucial to investigate the use of drugs among young people, considering that: 1) it is in youth that most people begin to use some type of drug; 2) early onset of this use is associated with a number of negative health outcomes; 3 ) trends in illicit drug use within this group are indicative of social and political changes to which young people are most sensitive; and 4) it is among young people that prevention activities have better results, reinforcing the need to evaluate and intervene early ${ }^{10}$. Considering that the university population is formed mainly by young people ${ }^{12-14}$, the relevance of studies on the use of drugs with this population stands out.

Although there are Brazilian studies describing the use of marijuana in the university population, they are mostly limited to descriptive analyzes or bivariate associations. Research indicates that being a male ${ }^{12,13}$, being influenced by the peers (friends or individuals in equivalent stages of development) $)^{15,16}$, and having relatives who use drugs $s^{17}$ are important risk factors for marihuana use. On the other hand, having a religious practice $^{12,18}$, and living with relatives ${ }^{19}$ are shown as protective factors. However, it is necessary to investigate these variables together, through analyzes that allow identifying the factors independently associated with the outcome.

Furthermore, there has been a recent change in the admission mechanism to undergraduate courses at most federal universities in Brazil. The new selection process is no longer conducted by the universities and is now centralized in the $\mathrm{Na}$ tional High School Examination (Exame Nacional do Ensino Médio - ENEM). This new model contributes to academic migration within the country due to the possibility to compete for a position in several universities around the country with a single test ${ }^{20}$. The raise in the number of undergraduate students from other cities may constitute a little-known risk factor.

Thus, the aim of this study was to measure the prevalence of marijuana use in the last month, its associated factors and its relationship with academic migration among undergraduate students of a federal university in southern Brazil.

\section{Methods}

\section{Design and participants}

This study has a cross-sectional design, and was conducted at the Federal University of Rio Grande (Universidade Federal do Rio Grande FURG). This public institution has approximately 8,000 undergraduate students in the campus of Rio Grande. Since 2010, its admissions are exclusively through ENEM.

The inclusion criteria of the study were to be 18 years or older; to study in the presential modality at the campus of Rio Grande; and to be enrolled in the year 2015. The exclusion criteria was to have abandoned the discipline at the time of the data collection, because locating those individuals one by one would harm the confidential and impersonal nature of the research.

\section{Sampling method and sample size calculation}

Our sampling strategy was based on the methods adopted on the I Levantamento nacional sobre o uso de álcool, Tabaco e outras drogas entre universitários das 27 capitais brasileiras ${ }^{10}$. It was a clustered systematic sampling, carried out in a single stage. Our reference system was the relation of all the classes taught for undergraduate courses in 2015. Classes were defined as the group of students enrolled in the same subject. 
Unlike most conventional surveys with clustered sampling, the elements in our research could be related to more than one cluster (e.g. one individual enrolled in two or more subjects drawn from the reference system). Also, individuals of the same cluster tend to be more homogeneous than if we had used a simple randomization sampling strategy. To address these issues, we calculated the design effect (deff), using as parameters an intraclass coefficient of 0.02 and a mean size of cluster of $20^{10}$, resulting in a deff of 1.5.

Two sample size calculations were carried out: one for prevalence (descriptive) and another for associated factors. The descriptive sample size calculation resulted in 1,290 individuals (parameters: $10 \%$ of the expected outcome's prevalence $^{10}$, with a margin of error of 2 percentage points; $80 \%$ of Power; and 5\% of significance level, $10 \%$ to possible losses and design effect of 1.5). The associated factor's sample size calculation resulted in 1,811 individuals (parameters: exposed/unexposed ratio of 1:4; prevalence ratio of $1.8,80 \%$ of Power; and $5 \%$ of significance level, $10 \%$ for possible losses and refusals, $15 \%$ for confounding factors and design effect of 1.5). The calculations indicated that it would be necessary 91 classes (1.811 individuals divided by the mean cluster size expected of $20^{10}$ ). We also added $10 \%$ to this final number of classes to account for the possibility of having individuals with less than 18 years old and of having participants in two or more clusters. Finally, it would be necessary 101 classes.

To conduct the systematic sampling of the clusters we calculated a sampling interval (jump), in order to select the classes from the reference system, which consisted of 2,107 classes. This number was derived from the ratio between the total number of classes $(\mathrm{N}=2,107)$ and the number of those required for our research $(n=101)$, resulting in a jump of 21 classes. The list was organized by institutes (13 in total) and by number of individuals enrolled (ranging from one to 110 ), in order to ensure the proportionality of the institutes in the final sample. A number from one to 21 was drawn to define the first class to compose the sample, resulting in the number 2. Hence, we started from the second class of this list, adding one in every 21 classes to our sample until we reach the 101 classes.

\section{Variables and instrument}

The instrument used was a self-administered and confidential questionnaire. Participants were questioned if they had ever tried marijuana in their lifes (lifetime use). In afirmative case, they had to answer if they used marijuana at least once in the last 12 months prior to the survey (last year use). If so, they were lastly asked about marijuana use the last 30 days (last month use), which was the outcome of this study. These questions were structured as advocated by the World Health Organization $(\mathrm{WHO})^{21}$. This way of assessing drug use is widely used, which allows comparability with most studies on drug use, regardless of the population or country in question.

The participants were also asked about socioeconomic, demographic and behavioral issues, specifically: sex; age; skin color; family income (in reais); marital status; city/state where they lived prior to their university entry (academic migration); religious practice; illicit drug use by relatives; illicit drug use by friends; tobacco use in the last month.

\section{Procedures}

A pilot study was conducted at the Federal University of Pelotas (Universidade Federal de Pelotas - UFPel). Application of the questionnaire was timed. Problems of interpretation were assessed and corrected for the final version of the instrument.

Data were collected between April and June of 2015. Students were informed that participation was voluntary and non-participation would not lead to individual harm. Those who agreed to participate were asked to sign a free and informed consent form. Each participant answered the instrument and deposited it in an urn, as a strategy to increase secrecy and reliability of the responses. Each class was visited at least twice in order to minimize study losses. After two visits, the classes that had more than 10 losses were revisited. Individuals who were not found in these revisits or who refused to participate were considered as losses. The fulfilled questionnaires were double typed by different professionals using Epidata version 3.1. Statistical analyzes were performed using Stata IC 13.1 software.

Univariate analysis were conducted to describe the sample, calculating the prevalence of the independent variables and the outcome. Bivariate analysis were carried out ir order to calculate the frequency of marijuana use in the last month associated with exposure variables. Wald's test for heterogeneity of proportions was used to verify if there was a significant difference in the outcome between the categories of the study's 
variables; the Wald's test for linear trend was used to test the hypothesis of a positive or negative relation between the prevalence of the outcome and ordinal categorical variables. The differences were described in prevalence ratios (PR), with the respective $95 \%$ confidence intervals (95\% CI) and $p$-values.

The multivariate (adjusted) analysis was carried out through Poisson regression with robust adjust for variance ${ }^{22}$. Thereunto, a hierarchical model of analysis was elaborated, in which the variables were controlled for those of the same or of higher levels. The variables were selected for the final model through the backward method. Only those variables with $p$-value $\leq 0.2$ were maintained in the model as a confounding control strategy. Estimates were calculated taking into account the design effect. The level of significance was set at 5\% for two-tailed tests. This study was approved by the Research Ethics Committee in the Health Area (Comitê de Ética em Pesquisa na Área da Saúde - CEPAS) of the Federal University of Rio Grande.

\section{Results}

Among the 101 classes drawn, eight were excluded because they did not had individuals enrolled. The final sample had 93 classes. In total, 2,459 enrollments were counted, of which 721 were ineligible for the following reasons: 251 were undergraduate students enrolled in more than one class, 54 were under 18 years of age, 416 had canceled their enrollment or had dropped out at the time of the research. Thus, the study had a total of 1,738 eligible individuals (average of 19 students per class).

We interviewed 1,423 undergraduate students, representing a response rate of $81.9 \%$. There were $18.1 \%$ of losses (15.6\% not found and $2.5 \%$ of refusals). We conducted a new calculation of design effect, resulting in 1.71, which was used in the multivariate analysis. The description of the sample in terms of demographic, socioeconomic and behavioral variables are presented in Table 1.

The sample was predominantly white $(78.7 \%)$, with ages ranging from 18 to 29 years $(79.2 \%)$. There was no predominance between sexes $(50.7 \%$ female). In addition, $43.8 \%$ of the sample came from other cities to study in this university and $39.8 \%$ reported having no religious practice. The median family income was $\mathrm{R} \$ 3,000.00$ (equivalent to 3.8 Brazilian mini- mum wages; interquartile range 1,500-5,764). Approximately two-thirds of the sample reported having a friend that had already used illicit drugs and $12.9 \%$ reported having relatives that had already used illicit drugs. The frequency of tobacco use in the last month was $16.1 \%$ (95\% CI $14.2 \%-18.0 \%$ ). The prevalence of marijuana use in the lifetime, last year and in the last month was $40.5 \%$ (95\% CI: $37.9 \%-43.0 \%$ ), $23.9 \%$ (95\% CI: $21.7 \%-26.1 \%)$ and $16.8 \%$ (95\% CI $14.8 \%-18.8 \%)$, respectively.

Data on the frequency of marijuana use in the last month according to the independent variables of this study, as well as the results of the crude and adjusted analyzes, are presented in Table 2. The highest prevalence of marijuana use in the last month were observed among those who reported tobacco use in the last month (46.7\%), who reported having relatives with lifetime use of any illicit drug (31.5\%) and who came from other states to study in the university $(27.1 \%)$. In both analysis (crude and adjusted), only skin color and family income were not associated with the outcome. After controlling for confounding effects, the risk factors that remained statistically significant were: being male $(\mathrm{PR}=1.65 ; 95 \% \mathrm{CI}$ 1.28 - 2.13); being single $(\mathrm{PR}=1,48 ; 95 \%$ CI 1,17 $-1,86)$; having relatives that had ever used any illicit drug (PR = 1.76; 95\% CI 1.40 - 2.22); having a friend that had ever used any illicit drug $(\mathrm{PR}=4.60 ; 95 \%$ CI $2.78-7.61)$; and last month tobacco use ( $\mathrm{PR}=2.94 ; 95 \%$ CI $2.27-3.81)$. We also identified a tendency to increase the probability of use as the age decreases ( $p$-value for linear trend $<0.001$ ) and the more distant the participants lived prior to the university ( $p$-value for linear trend $=0,01)$. Religious practice was shown to be a protective factor, with a decrease in the probability of use as increased its frequency ( $p$-value for linear trend $<0.001)$. The final model of the adjusted analysis had an adjusted $\mathrm{R}^{2}$ of $33.9 \%$.

\section{Discussion}

This study showed that the prevalence of marijuana use by undergraduate students is high in all measures (lifetime, last year and last month use). It is noteworthy that approximately half of all individuals who have ever experienced marijuana in their lives have also used it in the past month prior to the interview. The prevalence in this study $(16.8 \%)$ was approximately double the prevalence of Brazilian university students 
Table 1. Description of the FURG undergraduate student sample according to demographic, socioeconomic and behavioral variables. Rio Grande, Brazil. 2015.

\begin{tabular}{|c|c|}
\hline Variable & n (\%) \\
\hline \multicolumn{2}{|l|}{$\operatorname{Sex}(N=1,401)$} \\
\hline Female & $711(50.7)$ \\
\hline Male & $690(49.3)$ \\
\hline \multicolumn{2}{|l|}{ Age $(\mathrm{N}=1,307)$} \\
\hline 18 to 21 years & $520(39.8)$ \\
\hline 22 to 25 years & $362(27.7)$ \\
\hline 26 to 29 years & $153(11.7)$ \\
\hline 30 years or more & $272(20.8)$ \\
\hline \multicolumn{2}{|l|}{ Skin color $(N=1,410)$} \\
\hline White & $1,109(78.7)$ \\
\hline Black & $94(6.6)$ \\
\hline Brown or yellow & $207(14.7)$ \\
\hline \multicolumn{2}{|l|}{ Marital status $(\mathrm{N}=1,412)$} \\
\hline Single & $595(42.1)$ \\
\hline In a relationship & $477(57.9)$ \\
\hline \multicolumn{2}{|l|}{ Academic migration $(\mathrm{N}=1,387)$} \\
\hline City of the university & $780(56.2)$ \\
\hline Neighbor cities & $111(8.0)$ \\
\hline Cities of the same state & $391(20.2)$ \\
\hline Cities of other states & $216(15.6)$ \\
\hline \multicolumn{2}{|l|}{ Religious practice $(\mathrm{N}=1,414)$} \\
\hline Never & $563(39.8)$ \\
\hline Annually & $343(24.3)$ \\
\hline Monthly & $265(18.7)$ \\
\hline Weekly or daily & $243(17.2)$ \\
\hline \multicolumn{2}{|l|}{$\begin{array}{l}\text { Relatives that used illicit drug } \\
(\mathrm{N}=1,399)\end{array}$} \\
\hline No & $1,219(87.1)$ \\
\hline Yes & $180(12.9)$ \\
\hline \multicolumn{2}{|l|}{$\begin{array}{l}\text { Friend that used illicit drug } \\
(\mathrm{N}=1,410)\end{array}$} \\
\hline No & $511(36.3)$ \\
\hline Yes & $897(63.7)$ \\
\hline \multicolumn{2}{|l|}{ Tobacco use } \\
\hline Last month use $(\mathrm{N}=1,415)$ & $228(16.1)$ \\
\hline \multicolumn{2}{|l|}{ Marijuana use } \\
\hline Lifetime use $(\mathrm{N}=1,416)$ & $573(40.5)$ \\
\hline Last year use $(\mathrm{N}=1,416)$ & $338(23.9)$ \\
\hline Last month use $(\mathrm{N}=1,412)$ & $237(16.8)$ \\
\hline
\end{tabular}

Note: $\mathrm{n}=$ absolute frequency; $\%=$ prevalence.

$(9.1 \%)^{10}$ and almost nine times greater than the prevalence in the general population $(1.9 \%)^{2}$.

The greater prevalence of marijuana use among males is well established in the literatu$\mathrm{re}^{12-14,17,18,23,24}$. Research conducted with university students from four Andean countries (Peru,
Colombia, Chile and Ecuador) points out that the higher prevalence of marijuana use in males is related to the perception of easy access to the drug and lower perception of risk when compared with females ${ }^{25}$.

Studies conducted with the Brazilian general population and university students indicate that the age range of 18 to 24 years is especially vulnerable to illicit drug use ${ }^{2,3,10}$. In our research, we highlight an inverse trend between marijuana use and age. The probability of using marijuana in the last month ranged from a three-fold increase (in those aged 26-29 years) to seven-fold increase (18-21 years) compared to participants with 30 years of age or older. Younger students may expect to experience new freedom and enjoy their leisure time associated with their youth ${ }^{26}$.

The present study showed the protective role of religion, as it has been consistently pointed out in the scientific literature ${ }^{12,18,19,27,28}$. Furthermore, we assessed the involvement of the individual with the religious practice, through the periodicity in which religious cults or ceremonies were attended. As the individual reports a higher frequency of religious practice, the probability of marijuana use in the last month decreased, reaching $72 \%$ of protection in those who had weekly or daily practice. Religious practice may show this protective role by exerting direct influence on the individual and family relations, estimulating values of respect, greater self-control and less tolerance for deviations of conduct, such as drug use ${ }^{12}$.

The peer influence is highlighted when it is observed that $63.7 \%$ of the interviewees reported having a friend who uses or that had already used some type of illicit drug. A four-time greater probability of last month marijuana use by an individual in this group was observed when compared to those who reported having no friends who have ever used illicit drugs. This suggests the potential existence of a broad network of individuals using illicit drugs within the university, facilitating access to the $\mathrm{drug}^{15}$. In addition, it reinforces the findings of other studies that point out peer influence in the initiation and maintenance of illicit drugs use $\mathrm{e}^{15,17,29}$. The number of friends who use marijuana may be positively related to the number of opportunities to use it. Being invited to use marijuana more often can increase the likelihood of use ${ }^{15}$. Likewise, being single was also a risk factor. It is possible that single individuals are more vulnerable to peer influence due to their higher need for social acceptance, and hence more likely to use marijuana. 
Table 2. Crude and adjusted prevalence ratio for associations between marijuana use in the last month and independent variables. Multivariate analysis conducted with three hierarchical levels through Poisson regression with robust adjust for variance and design effect. Sample of FURG undergraduate students. Rio Grande, Brazil. 2015.

\begin{tabular}{|c|c|c|c|c|}
\hline Level & Variable & $\%$ & $\begin{array}{c}\text { Crude } \\
\text { PR (CI95\%) }\end{array}$ & $\begin{array}{c}\text { Adjusted } \\
\text { PR (CI95\%) }\end{array}$ \\
\hline \multirow[t]{16}{*}{$1^{\text {st }}$} & Sex & & $\mathrm{p}<0.001$ & $\mathrm{p}<0.001$ \\
\hline & Female & $13.2 \%$ & 1 & 1 \\
\hline & Male & $20.7 \%$ & $1.60(1.25-2.06)$ & $1.65(1.28-2.13)$ \\
\hline & Age & & $\mathrm{p}<0.001^{1}$ & $\mathrm{p}<0.001^{1}$ \\
\hline & 18 to 21 years & $23.0 \%$ & $6.73(3.59-12.61)$ & $6.73(3.62-12.53)$ \\
\hline & 22 to 25 years & $19.9 \%$ & $5.74(3.16-10.43)$ & $5.54(3.05-10.09)$ \\
\hline & 26 to 29 years & $11.1 \%$ & $3.13(1.41-6.95)$ & $2.94(1.32-6.56)$ \\
\hline & 30 years or more & $3.4 \%$ & 1 & 1 \\
\hline & Skin color & & $\mathrm{p}=0.088$ & $\mathrm{p}=0.390$ \\
\hline & White & $17.6 \%$ & 1 & 1 \\
\hline & Black, brown or yellow & $13.5 \%$ & $0.76(0.56-1.04)$ & $0.88(1.29-6.44)$ \\
\hline & Family income & & $\mathrm{p}=0.718$ & $\mathrm{p}=0.385$ \\
\hline & $1^{\text {st }}$ quartile (lower) & $17.1 \%$ & 1 & 1 \\
\hline & $2^{\text {nd }}$ quartile & $17.7 \%$ & $1.05(0.79-1.41)$ & $1.21(0.89-1.66)$ \\
\hline & $3^{\text {rd }}$ quartile & $14.7 \%$ & $0.87(0.58-1.30)$ & $0.91(0.60-1.40)$ \\
\hline & $4^{\text {th }}$ quartile (higher) & $18.1 \%$ & $1.06(0.77-1.44)$ & $1.09(0.77-1.56)$ \\
\hline \multirow[t]{12}{*}{$2^{\text {nd }}$} & Marital status & & $\mathrm{p}<0.001$ & $\mathrm{p}=0.001$ \\
\hline & Single & $22.6 \%$ & $1.87(1.52-2.30)$ & $1.48(1.17-1.86)$ \\
\hline & In a relationship & $12.4 \%$ & 1 & 1 \\
\hline & Academic migration & & $\mathrm{p}<0.001^{1}$ & $\mathrm{p}=0.010^{1}$ \\
\hline & $\begin{array}{l}\text { City of the university or } \\
\text { neighbor cities }\end{array}$ & $13.3 \%$ & 1 & 1 \\
\hline & Cities of the same state & $19.5 \%$ & $1.45(1.08-1.96)$ & $1.20(0.89-1.61)$ \\
\hline & Cities of other states & $27.1 \%$ & $2.01(1.55-2.62)$ & $1.50(1.11-2.02)$ \\
\hline & Religious practice & & $\mathrm{p}<0.001^{1}$ & $\mathrm{p}<0.001^{1}$ \\
\hline & Never & $25.4 \%$ & 1 & 1 \\
\hline & Annually & $15.3 \%$ & $0.61(0.43-0.85)$ & $0.59(0.42-0.84)$ \\
\hline & Monthly & $11.9 \%$ & $0.48(0.33-0.71)$ & $0.65(0.44-0.95)$ \\
\hline & Weekly or daily & $4.6 \%$ & $0.18(0.11-0.31)$ & $0.28(0.17-0.47)$ \\
\hline \multirow[t]{9}{*}{$3^{\text {rd }}$} & Relatives that used illicit drug & & $\mathrm{p}<0.001$ & $\mathrm{p}<0.001$ \\
\hline & No & $14.8 \%$ & 1 & 1 \\
\hline & Yes & $31.5 \%$ & $2.14(1.68-2.72)$ & $1.76(1.40-2.22)$ \\
\hline & Friend that used illicit drug & & $\mathrm{p}<0.001$ & $\mathrm{p}<0.001$ \\
\hline & No & $2.9 \%$ & 1 & 1 \\
\hline & Yes & $24.9 \%$ & $8.30(4.75-14.47)$ & $4.60(2.78-7.61)$ \\
\hline & Tobacco use in the last month & & $\mathrm{p}<0.001$ & $\mathrm{p}<0.001$ \\
\hline & No & $11.1 \%$ & 1 & 1 \\
\hline & Yes & $46.7 \%$ & $4.23(3.45-5.19)$ & $2.94(2.27-3.81)$ \\
\hline
\end{tabular}

Notes: $\%=$ outcome's prevalence by category; $\mathrm{PR}=$ prevalence ratio; CI95\% $=95 \%$ confidence interval. ${ }^{1}$ Wald's test for linear trend.

One important result of this research was that the academic migration within the country might contribute to the rise in the marijuana use among this population. Almost half of the interviewees lived in another city prior entering in the university $(43.8 \%)$ and this migration might be related to the admission process through ENEM. The greater the distance of the city of the participant prior to the university entry, the higher the prevalence of marijuana use in the last month, with an excess risk of $50 \%$ of use among those coming from other states. 
Individuals in this subgroup live away from their families. This can result in a lack of contact with family rules and monitoring, increasing opportunities for drug exposure and decreasing the capacity to refuse offers of drugs ${ }^{15,19}$. Furthermore, the geographical and cultural changes that these students face may lead them to the development of a distressful background, and it is possible that they engage with marijuana use to cope with these issues ${ }^{30}$.

Despite the fact that living with the family might play a protective role, having relatives who had ever used any illicit drug was a risk factor for marijuana use $(70 \%$ higher probability of this use). It is understood that the family can be both a risk and a protector factor insofar as there is a predisposition of the individual to learn and model their behaviors from examples obtained in the family ${ }^{17}$.

It is important to highlight that in the sample the prevalence of marijuana use in the last month was statistically equivalent to that of tobacco use in the last month. This result is surprising because both prevalences are high, but also because it emphasizes the ease of access to marijuana. In addition, tobacco use was associated with the use of marijuana $(\mathrm{PR}=2.89 ; 95 \%$ CI $2.29-3.65)$. Studies suggest that the first use of an illicit drug is preceded by the use of a licit drug, a transition that is commonly known as the gateway theory ${ }^{31}$.

Even though studies have pointed to higher prevalences of tobacco use in relation to marijuana ${ }^{10}$, there may be a reversal in this pattern in the university context, increasing the use of marijuana and reducing the consumption of tobacco. On one hand, the reduction of tobacco use may be an effect of Brazilian policy focusing on intersectoral actions for the control of tobacco smoking (increased taxation on cigarettes, legislation restricting the advertising of tobacco products and prohibiting tobacco smoke in closed places, as well as public health actions warning about the serious risks related to this use $)^{32}$. On the other hand, the increase in marijuana use may be associated with a reduction in the perception of the risk caused by its use ${ }^{11}$, as well as the opening of debates on legalization of the medicinal and recreational use of marijuana, as it is already occurring in the United States, Uruguay and Netherlands.
We understand that the results of this research can be extrapolated to other universities that have its admissions through ENEM, even though cultural, social and demographic differences should be taken into account. Academic migration occurs in universities all over Brazil and individuals moving to other cities to study may be exposed to the same risks that we identified in this sample.

\section{Limitations}

By the very nature of a cross-sectional design, it is not possible to make inferences about causality. Therefore, associations with behavioral variables (such as religious practice and tobacco use) are susceptible to reverse causality bias and should be interpreted with caution. In addition, marijuana use may be underreported due to the occurrence of false response bias and by the exclusion of individuals who have dropped out from the course at the time of data. Also, we were not able to gather information from those who were considered as losses, which may lead to a non respondent bias. Notwithstanding, this study had a higher response rate than the survey with a representative sample of Brazilian university students, which was $72.1 \%{ }^{33}$, indicating a success in the effort to reduce losses.

\section{Conclusion}

In conclusion, our findings suggest that the prevalence of marijuana use among undergraduate students at this university was high, especially when compared to the general and university population of Brazil. It is remarkable that the use of this illicit drug appeared to be equivalent to that of tobacco in this sample, suggesting a banalization of marijuana use, disregarding the possible health impairments that this use may entail. It is possible that academic migration within the country decreases the student's contact with family and increase vulnerability to peer influence, which may lead to a higher probability of marijuana use in this sample. Therefore, it is necessary to develop primary and secondary level interventions on illicit drug use, focusing on those individuals coming from other cities due to their greater exposure to the main identified risk factors and hence to marijuana use. 


\section{Collaborations}

LM Demenech - worked on the design of the research, fieldwork, data analysis and interpretation and writing of the manuscript. SS Paludo worked on the design of the research, review and approval of the final version of the manuscript to be published. SC Dumith - worked as general coordinator of the fieldwork, in data analysis and manuscript review. L Neiva-Silva - worked on the design of research, analysis and interpretation of data, writing of the manuscript and approval of the version to be published.

\section{Acknowledgements}

LM Demenech received a master's degree scholarship from CAPES (Coordenação de Aperfeiçoamento de Pessoal de Ensino Superior). SC Dumith is a research productivity fellow at $\mathrm{CNPq}$ (Conselho Nacional de Desenvolvimento Científico e Tecnológico).

\section{References}

1. United Nations Office on Drugs and Crime (UNODC). World Drug Report 2015. New York: UNODC; 2015.

2. Carlini EA, Galduróz JC, Silva AAB, Noto AR, Fonseca AM, Carlini CM, Oliveira LG, Nappo AS, Moura YG, Sanchez ZM. II Levantamento domiciliar sobre o uso de drogas psicotrópicas no Brasil: estudo envolvendo as 108 maiores cidades do país - 2005. São Paulo: Centro Brasileiro de Informações sobre Drogas Psicotrópicas; 2006.

3. Laranjeira R. II Levantamento Nacional de Álcool e Drogas (LENAD) - 2012. Brasilia: Instituto Nacional de Ciência e Tecnologia para Políticas Públicas de Álcool e Outras Drogas (INPAD); 2014.

4. Hill KP. Medical marijuana for treatment of chronic pain and other medical and psychiatric problems: A clinical review. JAMA 2015; 313(24):2474-2483.

5. Nugent SM, Morasco BJ, O’Neil ME, Freeman M, Low A, Kondo K, Elven C, Zakher B, Motu'apuaka M, Paynter R, Kansagara D. The Effects of Cannabis Among Adults With Chronic Pain and an Overview of General Harms: A Systematic Review. Ann Intern Med 2017; 167(5):319-331.

6. Lorenzetti V, Solowij N, Whittle S, Fornito A, Lubman DI, Pantelis C, Yücel M. Gross morphological brain changes with cronic, heavy cannabis use. Br J Psychiatry 2015; 206(1):77-78.

7. Weinberger AH, Platt J, Goodwin RD. Is cannabis use associated with an increased risk of onset and persistence of alcohol use disorders? A three-year prospective study among adults in the United States. Drug Alcohol Depend 2016; 161:363-367.

8. Rubino T, Zamberletti E, Parolaro D. Adolescent exposure to cannabis as a risk factor for psychiatric disorders. J Psychopharmacol 2012; 26(1):177-188.

9. Large M, Sharma S, Compton MT, Slade T, Nielssen O. Cannabis Use and Earlier Onset of Psychosis - A Systematic Meta-analysis. Arch Gen Psychiatry 2011; 68(6):555-561.

10. Andrade AG, Duarte PCAV, Oliveira LG. I Levantamento Nacional Sobre o Uso de Álcool, Tabaco e Outras Drogas Entre Universitários das 27 Capitais Brasileiras. São Paulo: Secretaria Nacional de Políticas sobre Drogas (SENAD); 2010.

11. Johnston LD, O'Malley PM, Bachman JG, Schulenberg JE, Miech RA. Monitoring the future - National survey results on dru use, 1975-2013: Volume 2, College students and adults age 19-55. Ann Arbor: Institute for Social Research; 2014.

12. Gomes FC, Andrade AG, Izbicki R, Moreira-Almeida A, Oliveira LG. Religion as a protective factor against drug use among Brazilian university students: a national survey. Rev Bras Psiquiatr 2013; 35(1):29-37.

13. Kerr-Corrêa F, Andrade AG, Bassit AZ, Boccuto NMVF. Uso de álcool e drogas por estudantes de medicina da Unesp. Rev Bras Psiquiatr 1999; 21(2):95100. 
14. Oliveira LG, Barroso LP, Wagner GA, Ponce JC, Malbergier A, Stempliuk VA, Andrade AG. Drug consumption among medical students in São Paulo, Brazil: influences of gender and academic year. Rev Bras Psiquiatr 2009; 31(3):227-239.

15. Pinchevsky GM, Arria AM, Caldeira KM, Garnier-Dykstra LM, Vincent KB, O'Grady KE. Marijuana exposure opportunity and initiation during college: Parent and Peer Influences. Prev Sci 2012; 13(1):4354.

16. Portugal FB, Souza RS, Bualz V, Siqueira MM. Uso de drogas por estudantes de Farmácia da Universidade Federal do Espírito Santo. J Bras Psiquiatr 2008; 57(2):127-132.

17. Kassa A, Taddesse F, Yilma A. Prevalence and factors determining psychoactive substance (PAS) use among Hawassa Univeristy (HU) undergraduate students, Hawassa Ethiopia. BMC Public Health 2014; 14:1044.

18. Silva LVER, Malbergier A, Stempliuk VA, Andrade AG. Fatores associados ao consumo de álcool e drogas entre universitários. Rev Saude Publica 2006; 40(2):280288.

19. Ansari WE, Vallentin-Holbech L, Stock C. Predictors of Illicit Drug/s Use Among University Students in Northern Ireland, Wales and England. Glob J Health Sci 2015; 7(4):18-29.

20. Andriola WB. Doze motivos favoráveis à adoção do Exame Nacional do Ensino Médio (ENEM) pelas Instituições Federais de Ensino Superior. Ensaio: aval pol públ Educ 2011; 19(70):107-126.

21. World Health Organization (WHO). A methodology for student drug-use surveys. Geneva: WHO; 1980.

22. Barros AJD, Hirakata VN. Alternatives for logistic regression in cross-sectional studies: an empirical comparison of models that directly estimate the prevalence ratio. BMC Med Res Methodol 2003; 3:21.

23. Lucas ACS, Parente RCP, Picanço NS, Conceição DA, Costa KRC, Magalhães IRS, Siqueira JC. Uso de psicotrópicos entre universitários da área da saúde da Universidade Federal do Amazonas, Brasil. Cad Saude Publica 2006; 22(3):663-671.

24. Morales GI, Del Valle CR, Belmar CM, Orellana YZ, Soto AV, Ivanovic DM. Prevalencia de consumo de drogas en estudiantes universitarios que cursan primer y cuarto año. Rev Med Chile 2011; 139(12):15731580.

25. Hynes M, Demarco M, Araneda JC, Cumsille F. Prevalence of marijuana use among university students in Bolivia, Colombia, Ecuador and Peru. Int J Environ Res Public Health 2015; 12:8.

26. Oliveira LG, Alberghini DG, Santos B, Andrade AG. Polydrug use among college students in Brazil: a nationwide survey. Braz J Psychiatry 2013; 35(3):221230 .
27. Stempliuk VA, Barroso LP, Andrade AG, Nicastri S, Malbergier A. Comparative study of drug use among undergraduate students at the University of São Paulo - São Paulo campus in 1996 and 2001. Rev Bras Psiquiatr 2005; 27(3):185-193.

28. Suerken CK, Reboussin BA, Sutfin EL, Wagoner KG, Spangler J, Wolfson M. Prevalence of marijuana use at college entry and risk factors for initiation durgin freshman year. Addict Behav 2014; 39(1):302-307.

29. Allen JP, Chango J, Szwedo D, Schad M, Martson E. Predictors of susceptibility to peer influence regarding substance use in adolescence. Child development 2012; 83(1):337-350.

30. Hyman SM, Sinha R. Stress-Related Factors in Cannabis Use and Misuse: Implications for Prevention and Treatment. J Subst Abuse Treat 2009; 36(4):400-413.

31. Castaldelli-Maia JM, Martins SS, Oliveira LG, Andrade AG, Nicastri S. The role of drug use sequencing pattern in further problematic use of alcohol, tobacco, cannabis, and other drugs. J Ment Health 2015; 24(1):9-14.

32. Schmidt MI, Duncan BB, Silva GA, Menezes AM, Monteiro CA, Barreto SM. Chronin non-communicable diseases in Brazil: burden and current challenges. Lancet 2011; 377(9781):1949-1961.

33. Castaldelli-Maia JM, Martins SS, Oliveira LG, Van Laar M, Andrade AG, Nicastri S. Use transition between illegal drugs among Brazilian university students. Soc Psychiatry Psychiatr Epidemiol 2014; 49:10.
Artigo apresentado em 07/08/2017 Aprovado em 20/11/2017

Versão final apresentada em 22/11/2017 
